\title{
Genetic diversity of two Portuguese populations of the pullet carpet shell Venerupis senegalensis, based on RAPD markers: contribution to a sustainable restocking program
}

\author{
Sandra Joaquim $\cdot$ Jorge Pereira $\cdot$ Alexandra Leitão $\cdot$ \\ Domitília Matias • Raquel Chaves • Henrique Guedes-Pinto • \\ Luís Chícharo $\cdot$ Miguel Gaspar
}

Received: 12 May 2009/Revised: 16 November 2009/Accepted: 20 November 2009/Published online: 2 December 2009

(C) Springer-Verlag and AWI 2009

\begin{abstract}
The pullet carpet shell Venerupis senegalensis $(=V$. pullastra $)$ is a commercially important species in Portugal, Spain, France, and Italy. In Portugal, this species was once abundant in the Ria Formosa (southern Portugal). However, in the early 1980s, its abundance declined dramatically due to overfishing. In order to reverse this negative trend, the genetic sustainable management of the wild stocks of $V$. senegalensis should be performed by promoting successful restocking actions and the development of an aquaculture commercial production program of this species. In order to find the best broodstock for aquaculture purposes and therefore minimize the deleterious effects of hatchery practices, we analyzed the genetic diversity of the natural population to be restocked (Ria Formosa) but also of another potential genetically close population (Ria de Aveiro) by RAPD. Similar and substantive percentage of polymorphic loci, effective number of alleles, Nei's gene diversity, and Shannon's diversity index was found within both populations. This high genetic variability within populations suggests that they might have a gene pool with
\end{abstract}

Communicated by H.-D. Franke.

S. Joaquim $(\bowtie) \cdot$ A. Leitão $\cdot$ D. Matias · M. Gaspar

Instituto Nacional de Recursos Biológicos (INRB, I.P.)/IPIMAR,

Av. 5 de Outubro s/n, 8700-305 Olhão, Portugal

e-mail: sandra@ipimar.pt

J. Pereira $\cdot$ R. Chaves $\cdot$ H. Guedes-Pinto

Centro de Genética e Biotecnologia (CGB),

Instituto de Biotecnologia e Bioengenharia (IBB),

Universidade de Trás-os-Montes e Alto Douro,

5000-911 Vila Real, Portugal

L. Chícharo

Centro de Ciências do Mar (CCMAR), Universidade do Algarve,

Campus de Gambelas, 8005-139 Faro, Portugal sufficient genetic plasticity to support changes in the environmental conditions. Analyses of population genetic structure also revealed a small genetic differentiation between the two populations. The high genetic variability of the natural population to be restocked makes it the preferential broodstock for aquaculture purposes. However, the Ria de Aveiro population could also be a viable alternative, due to its genetic plasticity and the genetic similarity of both populations. The results of this study can be useful to the sustainable management of wild stocks as well as in promoting successful restocking actions based on aquaculture production.

Keywords Genetic diversity - Pullet carpet shell . RAPDs · Sustainable management .

Venerupis senegalensis

\section{Introduction}

The pullet carpet shell Venerupis senegalensis $(=V$. pullastra) is an Atlantic-Mediterranean warm-temperate species that inhabits sandy to muddy bottoms, usually from the low tide mark to a depth of $40 \mathrm{~m}$ (Macedo et al. 1999). This species is commercially exploited in Portugal, Spain, France, and Italy. In Portugal, V. senegalensis occurs in estuaries and coastal lagoons. Presently, this species is more abundant on the western coast, namely in the Ria de Aveiro coastal lagoon (Maia et al. 2006). The pullet carpet shell was also once abundant in the Ria Formosa lagoon (southern Portugal). However, in the early 1980s, the abundance of this species declined dramatically due to overfishing (Massapina and Arrobas 1991). Despite the high commercial value of this species, the lack of interest presented nowadays by local fishermen in harvesting this 
species leads us to suppose that the population density in Ria Formosa has decreased below a threshold level, such that natural recovery does not appear to be possible.

An active intervention seems, therefore, necessary to restore stocks to reproductive viability. In order to do so and try to reverse this negative trend, a project to produce larvae and juveniles of $V$. senegalensis has been implemented aiming to test different technical approaches to restock this species in the Ria Formosa. This restock action can be performed in already existent bivalve-beds of Ria Formosa. In this way, $V$. senegalensis can be valorized as an aquaculture product and as a possible alternative to Ruditapes decussatus, the most important bivalve produced in this lagoon. Hatchery practices may have deleterious effects on the genetic makeup of the released stock, and consequently a deleterious effect on the wild population, such as the increasing genetic homogeneity (Ward 2006). The decline of productivity and viability of the naturally spawning of three species of wild Pacific salmonids when hybridized with hatchery produced species of lower fitness (Reisenbichler and Rubin 1999) and the genetic homogenization of the pearl oyster stocks by the impacts of transplants (Arnaud-Haond et al. 2004) are two examples of that.

Conscientious broodstock selection and husbandry could nonetheless minimize or eliminate this negative effect, enhancing the creation of positive outcomes from restocking. Since wild populations represent the primary source of genetic variability for aquaculture stocks (Alarcón et al. 2004), the broodstock should be obtained from the natural population to be restocked or, if polymorphism of this population is proven to be low and the population to be in genetic decline, from the genetically close population. In order to develop sustainable aquaculture and conscientious restocking programs, to ensure appropriate broodstock management programmes and effective breeding programmes, it is of utmost importance to study the range of genetic variation, genetic structure, diversification trend, and other factors affecting genetic structure of the different populations of this species.

To the author's best knowledge, no population genetic studies were performed until now in populations of $V$. senegalensis. Only a study with ELISA and PCR-RFLP data was performed for species identification (Fernández et al. 2002). The Random Amplified Polymorphic DNA (RAPD) method has been frequently applied to reveal population genetic variation, divergence, and biogeography (Schaal and Leverich 2001). This low cost technique, using short oligonucleotides of arbitrary sequence for amplification of discrete regions of the genome, is simple, not requiring much in up-front resources, no need for prior DNA sequence knowledge, and represents the entire genome (nuclear and mtDNA; Williams et al. 1990; Star et al.
2003). In marine bivalves, RAPD technique has been extensively used in population genetic studies, in oysters (e.g., Liu and Dai 1998), mussels (e.g., Star et al. 2003; Toro et al. 2004), and scallops (e.g., Heipel et al. 1998), and proved to be an appropriate tool at the molecular level for the identification of the divergence between populations or sibling species (Yu et al. 2004). In order to assess the most appropriate $V$. senegalensis founder population to develop an aquaculture production program of this species and for restocking purposes and since no information is currently available on Portuguese population genetic structure of $V$. senegalensis, the Ria Formosa population (to be restocked) and the Ria de Aveiro population were analyzed by RAPD techniques.

\section{Materials and methods}

\section{Sample collection}

Samples of V. senegalensis were hand-collected from two locations in Portugal: Ria Formosa (southern coast $37^{\circ} 01^{\prime} \mathrm{N} ; 07^{\circ} 49^{\prime} \mathrm{W}$ ) and Ria de Aveiro (western coast $40^{\circ} 42^{\prime} \mathrm{N}$; $08^{\circ} 40^{\prime} \mathrm{W}$; Fig. 1), both are shallow water mesotidal lagoons with semidiurnal tidal regimes that constitute the major hydrodynamic forcing (Nobre et al. 2005; Dias et al. 2000). These lagoons, that distance $500 \mathrm{~km}$ from each other, have several channels and a large intertidal area covered by sand, muddy sand-flats, and salt marshes (Falcão and Vale 1990; Picado et al. 2009). Ria Formosa has an extension of $55 \mathrm{~km}$ and a maximum width of $6 \mathrm{~km}$ (Newton and Mudge 2003). The lagoon is separated from the Atlantic Ocean by several barrier islands and two peninsulas. The tidal range varies from $1.35 \mathrm{~m}$ on neap tides to $3 \mathrm{~m}$ on spring tides, and the coefficient of renovation for the lagoon is 3.2 for a spring tide and 1.0 for a neap tide. The freshwater inputs are almost negligible and salinity remains close to 36\% (Falcão and Vale 1990; Águas 1986). The Ria de Aveiro is $45 \mathrm{~km}$ long and $10 \mathrm{~km}$ wide, being connected to the Atlantic Ocean by only a narrow channel (Picado et al. 2009), and the tidal amplitude is $0.6 \mathrm{~m}$ in neap tides and $3.2 \mathrm{~m}$ in spring tides (Dias et al. 2000). This lagoon has an important freshwater input coming from the Vouga and the Antuã rivers (Moreira et al. 1993; Dias et al. 2000). These two ecosystems are currently used for clam production and fish aquaculture ponds.

\section{Sample processing and DNA extraction}

The adductor muscles of 20 individuals $(35-37 \mathrm{~mm}$ ) of each location were dissected from fresh specimens and immediately stored at $70 \%$ ethanol until DNA extraction. Genomic DNA was extracted from approximately $15 \mathrm{mg}$ 


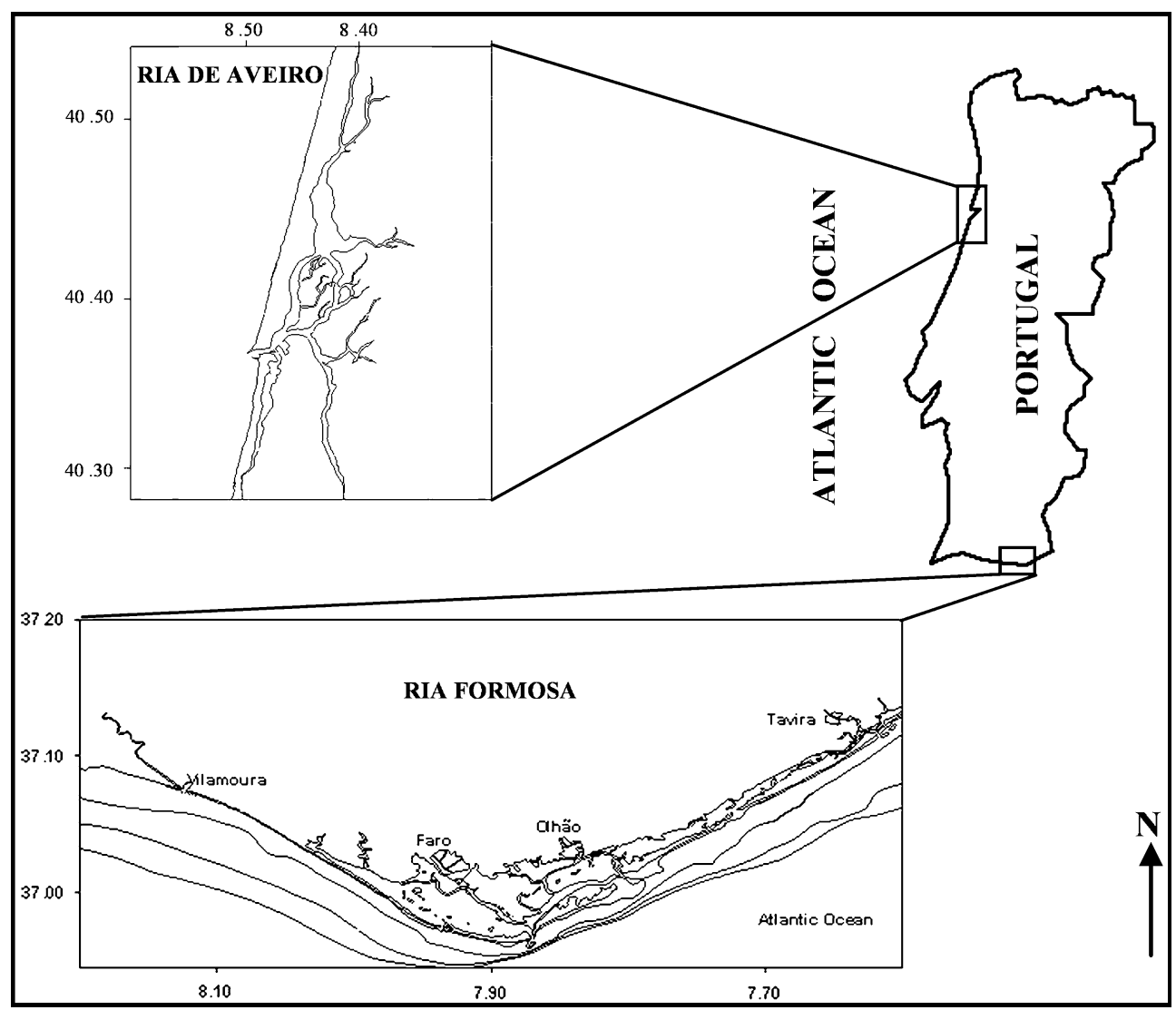

Fig. 1 Ria Formosa and Ria de Aveiro locations

of the muscle tissue following Pereira (2008) by using a QuickGene DNA tissue kit and a Quickgene-810 automatic nuclei acid isolation system (Fuji Photo Film Co., Ltd, Life Science Products Division, Tokyo, Japan).

\section{RAPD amplification}

Since the reproducibility has been pointed out as the major RAPD's limitation (Harris 1999), a series of optimization experiments were conducted, in which 20 decanucleotide RAPD primers (Operon Technologies, Alameda, CA, USA) were screened in which 6 primers were selected on their ability to amplify reproducible and easily scorable bands. The amplifications were performed in a $25 \mu \mathrm{l}$ of reaction volume containing $1 \times T a q$ polymerase buffer (Tris-HCl $200 \mathrm{mmol} / \mathrm{l} \mathrm{pH} \mathrm{8.3,} \mathrm{KCl} 500 \mathrm{mmol} / \mathrm{l}, 0.5 \%$ Triton-X 100), $2.0 \mathrm{mM} \mathrm{MgCl}, 100 \mu \mathrm{M}$ of each dNTPs (dATP, dCTP, dGTP, dDTTP; Invitrogen, Life Sciences), $0.2 \mu \mathrm{M}$ of primer, 0.5 U Taq polymerase (Fermentas, Canada), $50 \mathrm{ng}$ of genomic DNA, and water. Initial denaturation was for $3 \mathrm{~min}$ at $94^{\circ} \mathrm{C}$, followed by 44 cycles of $1 \mathrm{~min}$ at $94^{\circ} \mathrm{C}, 1 \mathrm{~min}$ at the optimal annealing temperature $\left(36^{\circ} \mathrm{C}\right), 2 \mathrm{~min}$ at $72^{\circ} \mathrm{C}$, and a final extension step of $10 \mathrm{~min}$ at $72^{\circ} \mathrm{C}$. The samples were finally cooled at $4^{\circ} \mathrm{C}$.
Amplification products were analyzed by electrophoresis on $2 \%$ agarose TBE (Tris borate EDTA) gels stained with ethidium bromide and then visualized with ultraviolet light, and image were saved in UVIDOC (UVItec). A DNA ladder mix (Fermentas, Canada) was used as a molecular ruler. To avoid inaccuracy in scoring due to differences in gels, two lines of control molecular ladder were included in each set of samples for each gel.

\section{Data analysis}

Amplified fragments were scored as binary data, i.e., presence as one and absence as zero. The differences in band intensities were not taken into account to avoid errors introduced by competition among priming sites during the initial rounds of PCR (Bachmann 1997). The matrix of RAPDs data was analyzed on the basis of the following genetic parameters: number of polymorphic loci, percentage of polymorphic loci, observed number of alleles $\left(n_{0}\right)$, effective number of alleles $\left(n_{\mathrm{e}}\right)$, Nei's genetic diversity $(h)$, Shannon's information index $(H), G_{\mathrm{ST}}$, and the effective migrants number by generation $\left(N_{\mathrm{m}}\right.$; Wright 1951$)$, using POPGENE program version 1.32 (Yeh et al. 1997; available at http://www.ualberta.ca/ fyeh/). TFPGA program 
Table 1 Primers selected for RAPD analyses

\begin{tabular}{lllll}
\hline Primer & Sequence $\left(5^{\prime}-3^{\prime}\right)$ & $\% \mathrm{GC}$ & $T_{\mathrm{m}}$ & $\begin{array}{l}\text { No of score } \\
\text { bands }\end{array}$ \\
\hline OPE-02 & GGTGCGGGAA & 70 & 36 & 32 \\
OPE-03 & CCAGATGCAC & 60 & 36 & 35 \\
OPE-06 & AAGACCCCTC & 60 & 36 & 39 \\
OPE-08 & TCACCACGGT & 60 & 36 & 40 \\
OPE-11 & GAGTCTCAGG & 60 & 36 & 40 \\
OPE-16 & GGTGACTGTG & 60 & 36 & 37 \\
\hline
\end{tabular}

version 1.3 (Miller 1997; available at http://www.marksgeneticsoftware.net/tfpga.htm) was also used to calculate the Nei's (1978) genetic distance and fixation $F_{\text {st }}$ value, over loci, based on Lynch and Milligan's (1994) Taylor expansion estimate and assumed a HardyWeinberg equilibrium. Significant levels were assessed by permutation of the alleles (multilocus genotypes) within populations.

\section{Results}

The 6 decanucleotide RAPD primers generated a total of 222 reproducible and clear amplification bands, with fragments ranging in molecular size from approximately $200-1,500 \mathrm{bp}$. The bands produced per primer ranged from 32 (OPE-02 primer) to 40 (OPE-08 and OPE-11; Table 1), and the average band loci per primer was 37.17. The percentage of polymorphic loci found was $86.55 \%$ in the Ria Formosa $V$. senegalensis population and $87.44 \%$ in the Ria de Aveiro one. The number of effective alleles per locus was 1.3545 and 1.3219 for Ria Formosa and Ria de Aveiro populations, respectively. The values of genetic diversity and the Shannon's information index for Ria Formosa $(h=0.2276 ; \quad H=0.3608)$ and for Ria de Aveiro ( $h=0.2105 ; H=0.3394$ ) revealed a high level of gene diversity in both populations and did not vary considerably between them, (Table 2).

The Nei's (1978) values (0.064) revealed a small genetic distance between the two populations. The value of the total genetic diversity $(\mathrm{Ht})$ was 0.246 and the genetic diversity within populations (Hs) was 0.2190 . The $G_{\text {st }}$ index value was 0.1097 , meaning that most of the genetic variation was found within populations $(89.03 \%)$. Assuming Hardy-Weinberg equilibrium, $F_{\text {st }}$ value (0.1659) showed no evidence of genetic differentiation between populations. The genetic flow $\left(N_{\mathrm{m}}\right)$ between the two populations was 4.057 .

\section{Discussion}

Assessment of genetic variation is an important step toward the implementation of species conservation strategies. Ward (2006) summarized that the high level of genetic variability in invertebrates strongly depends on its life form, geographic range, and larval dispersal mechanism. A variety of genetic markers has been used to determine aquatic populations structure. These include the use of allozyme, RAPD, restriction fragment length polymorphism (RFLP), and microsatellite markers (Yan et al. 2005). RAPD markers have been widely used for estimating genetic diversity and genetic structure in many species and have proved to be a powerful tool (Bussell 1999; Ouborg et al. 1999; Chen et al. 2005). In our study, this methodology was efficient in obtaining information on the population genetics of $V$. senegalensis.

Analysis of RAPD data from the 40 individuals revealed similar and substantive percentage of polymorphic loci, effective number of alleles, and Nei's gene diversity within $V$. senegalensis populations. The values obtained in our study are slightly lower than the ones found for other bivalves, such as in mussel (Mytilus galloprovincialis) populations in Southern California (Li Ma et al. 2000) or in European populations of the razor clam Ensis siliqua (Fernández-Tajes et al. 2007), but are similar to the one's obtained in another veneroid species ( $R$. decussatus) populations in Algarve coast (Southern Portugal; Pereira 2008). Shannon's diversity index is well suited to the analysis of RAPD data as it is relatively insensitive to the bias produced by failures to detect heterozygous individuals (Dawson et al. 1995). The values obtained with this index confirmed the high genetic variability in both populations. They were, however, lower than those observed in populations of $R$. decussatus by Pereira (2008), which might be explained by the larger populations size of that study. The high genetic variability found in both $V$. senegalensis populations suggests that they have a gene pool with sufficient genetic plasticity to support changes in the environmental conditions without endangering the species survival, even in the case of an overfished population like

Table 2 Genetic variability at the two Venerupis senegalensis populations detected by RAPD

\begin{tabular}{llllll}
\hline Population & $\begin{array}{l}\text { Polymorphic } \\
\text { loci }(\%)\end{array}$ & $\begin{array}{l}\text { Observed number } \\
\text { of alleles }\left(n_{0}\right)\end{array}$ & $\begin{array}{l}\text { Effective number } \\
\text { of alleles }\left(n_{\mathrm{e}}\right)\end{array}$ & $\begin{array}{l}\text { Nei's gene } \\
\text { diversity }(h)\end{array}$ & $\begin{array}{l}\text { Shannon's information index } \\
(H)\end{array}$ \\
\hline Ria Formosa & 86.55 & 1.8655 & 1.3545 & 0.2276 & 0.3608 \\
Ria de Aveiro & 87.44 & 1.8744 & 1.3219 & 0.2105 & 0.3394 \\
\hline
\end{tabular}


the Ria Formosa one's. Indeed, the ability of a species to respond adaptively to environmental changes and, therefore, to long-term survival depends on the levels of genetic variability within populations (Qian et al. 2001; Sofia et al. 2006). Fernández-Tajes et al. (2007) also reported a high genetic variability for an Ensis siliqua Portuguese population which has suffered strong declines due to overfishing.

The results of the population genetic structure of $V$. senegalensis analyses revealed a small genetic differentiation between the two populations. Similar levels of genetic differentiation, using the same methodology, have been recorded between populations of other bivalves (Star et al. 2003; Casu et al. 2005; Fernández-Tajes et al. 2007; Pereira 2008). The main factors that might determine the population genetic structure of bivalve species include mating and reproductive system, gene flow (dispersal of larvae), genetic drift, environmental selection or adaptation, bottlenecks, and founder effects among others (e.g., Bierne et al. 1998; Holmes et al. 2004). The high values of genetic variability within populations and low levels of genetic variation among populations observed in this study can be a consequence of the reproductive system of $V$. senegalensis. As in most marine bivalves, it is characterized by high fecundity, large population sizes, external fertilization with broadcast spawning, and extensive larval dispersal (Bierne et al. 1998). At a first view, the results geared for the studied populations suggest a "canonical" model of population genetics known as panmixia, without inbreeding, proposed for other bivalve populations (e.g., Bierne et al. 1998; Fernández-Tajes et al. 2007). This model requires an intense gene flow $\left(N_{\mathrm{m}}\right)$ between populations without geographic barriers in order to allow them to evolve together (Armbruster 1997, 1998; Ward 2006). Traditionally, levels of $N_{\mathrm{m}}>1$ are thought to be sufficient to prevent population genetic differentiation (Slatkin 1987). Thus, the number of migrants between the studied populations $\left(N_{\mathrm{m}}=4.057\right)$ may suggest that larval exchange could be responsible for the genetic similarities between them. Fernández-Tajes et al. (2007) reported a gene flow of the same magnitude among Galician populations of E. siliqua and they suggested that these populations acted as a single interbreeding population, and Pereira (2008) also obtained an $N_{\mathrm{m}}=2.9$ between two populations of $R$. decussatus from Ria Formosa and from a near lagoon (Ria de Alvor). However, some authors (Whitlock and McCauley 1999) believe that these results should be interpreted carefully, since $N_{\mathrm{m}}$ is calculated based on the $F$ st value, and the genetic plasticity of both populations (high genetic variability) can contribute to their similarity. V. senegalensis is an actaeplanic species, i.e., with potential for dispersal (Ropes 1979; Havenhand 1995; Casu et al. 2005), and Ria Formosa and Ria de
Aveiro, despite the fact that they are shallow lagoons systems, have a high tidal flow that allows a large water renovation of both lagoon systems and that may promote larval drift to the coastal waters, could be a possible vector responsible for larvae dispersal and consequent genetic similarity of the studied populations. Nevertheless, we believe that the short larval life spans of $V$. senegalensis that is of around 15 days, the $500 \mathrm{~km}$ that geographically distanced Ria Formosa from Ria de Aveiro and other oceanic physical constraints (e.g., variation in water temperature, salinity, predation, and currents) can restrict the dispersal capacity of larvae. These facts do not support the previous hypotheses of larval exchange between the two $V$. senegalensis populations.

Nonetheless, natural dispersal is not always the operating transport mechanism (Levin 2006). The genetic structure of natural populations can be significantly affected by anthropogenic activities (Palumbi 2001; Simmons et al. 2006; Pereira 2008). Nowadays, there is no knowledge of market exchanges involving $V$. senegalensis between the two studied sites owing to the overfishing of Ria Formosa population, but an historical involvement of fishermen from Aveiro in Algarve fisheries (Oliveira FXd'A 1906; Garrido and Carvalho 2007) and the crescent importance of bivalve market in both sites can be a possible vector to contribute to the transplantation of $V$. senegalensis between those two lagoons and consequently to the genetic similarity between the two studied populations. This hypothesis can lead us to suggest that the high levels of $N_{\mathrm{m}}$ between the two populations can result from historically genotypic and allelic similarities between the individuals from these regions and do not reflect the present day value of $N_{\mathrm{m}}$. This hypothesis was already conjectured by Star et al. (2003) for New Zeland Perna canaliculus populations.

Bell et al. (2005) have showed that the knowledge of spatial population structure is pivotal to efficient management of marine invertebrate fisheries. According to Gaffney (2006), three primary genetic concerns should be taken in consideration before implementing shellfish restoration projects: (1) identification and use of the correct genetic material for producing hatchery lines; (2) maintenance of genetic variability in hatchery stocks; and (3) maintaining $N_{\mathrm{e}}$ in the wild population. Given that $V$. senegalensis population of Ria Formosa still presents a high intrapopulation genetic variability, it should be the one preferentially selected as broodstock for aquaculture purposes and for subsequent restocking program. However, if the broodstock available from this population reveals to be insufficient due to severe overfishing, Ria de Aveiro population could be a viable alternative. Indeed, we have showed in this study that by one hand genetic plasticity is high and by other hand both population presented genetic similarity. Furthermore, when designing restocking actions 
based on aquaculture production, we should nevertheless always try to ensure the preservation of the genetic variability in the hatchery stocks and maintaining the effective size $\left(N_{\mathrm{e}}\right)$ of the wild population to be restored. In addition to the favorable genetic factors, the similarities between Ria Formosa and Ria de Aveiro in terms of habitat (both shallow water mesotidal lagoon with a large intertidal area covered and with similar semidiurnal tidal regimes, salinity, and sediment) can also positively influence the success of a restocking program. The results of this study provided useful information on the genetic structure of two Portuguese populations of the pullet carpet shell. This data can be useful to the sustainable management of wild stocks as well as in promoting successful restocking actions based on aquaculture production. The protection of genetic diversity in the Ria Formosa population should, however, always be a primary aim of any restocking program to be performed.

Acknowledgments We thank the IPIMAR Aveiro staff and João Joaquim, for providing the Ria de Aveiro and Ria Formosa clam samples, respectively. The authors also thank the Maritime Museum of Ílhavo for the historical documents and to A. Good and J. White for English editing. This study was funded by the Promopesca (Interreg IIIA) project.

\section{References}

Águas MPN (1986) Simulação da circulação hidrodinâmica na Ria Formosa. In Os sistemas Lagunares do Algarve. Seminário comemorativo do dia mundial do ambiente. Universidade do Algarve, Faro, 5-7 Junho 1985, pp 78-90

Alarcón JA, Magoulas A, Georgakopoulos T et al (2004) Genetic comparison of wild and cultivated European populations of the Gilthead Sea bream (Sparus aurata). Aquaculture 230:65-80

Armbruster G (1997) Genetische verarmung aufgrund von populationseinbrüchen: Eine analyse bei der seltenen landschneckenart Cochlicopa ninens (Gallenstein, 1848). Nat Landsc 2:444-446

Armbruster G (1998) Bei einer verbreiteten landschnecke Cochlicopa lubrica (O. F. Müller), wird die frequenz von molekularem ph_notypen durch selbstbefruchtung und habitatspezifische selektion beeinflubt. Laufener Seminarbeitrãge 2/98 der Bayerischen Akademie für Naturschutz und landschaftspflege (ANL) 39-49

Arnaud-Haond S, Vonau V, Bonhomme F et al (2004) Spatiotemporal variation in the genetic composition of wild populations of pearl oyster (Pinctada margaritifera cumingii) in French Polynesia following 10 years of juvenile translocation. Mol Ecol 13:2001-2007

Bachmann K (1997) Nuclear DNA markers in plant biosystematic research. Opera Bot 132:137-148

Bell JD, Rothlisberg PC, Munro JL et al (2005) Restocking and stock enhancement of marine invertebrate fisheries. Adv Mar Biol 49:1-370

Bierne N, Launey S, Naciri-Graven Y et al (1998) Early effect of inbreeding as revealed by microsatellite analyses on Ostrea edulis larvae. Genetics 148:1893-1906

Bussell JD (1999) The distribution of random amplified polymorphic DNA (RAPD) diversity amongst populations of Isotoma petraea (Lobeliaceae). Mol Ecol 8:775-789
Casu M, Maltagliati F, Cossu P et al (2005) Fine-grained spatial genetic structure in the bivalve Gemma gemma from Maine and Virginia (USA), as revealed by inter-simple sequence repeat markers. J Exp Mar Biol Ecol 325:46-54

Chen SL, Xia T, Chen SY et al (2005) RAPD profiling in detecting genetic variation in endemic Coelonema (Brassicaceae) of Qinghai-Tibet Plateau of China. Biochem Genet 43:189-201

Dawson IK, Simons AJ, Waugh R et al (1995) Diversity and genetic differentiation among subpopulations of Gliricidia sepium revealed by PCR-based assays. Heredity 74:10-18

Dias JM, Lopes JF, Dekeyser I (2000) Tidal propagation in Ria de Aveiro lagoon, Portugal. Phys Chem Earth (B) 25:369-374

Falcão M, Vale C (1990) Study of the Ria Formosa ecosystem: benthic nutrient remineralization and tidal variability of nutrients in the water. Hydrobiologia 207:137-146

Fernández A, García T, Asensio L et al (2002) Identification of the clam species Ruditapes decussatus (Grooved Carpet Shell), Venerupis rhomboides (Yellow Carpet Shell) and Venerupis pullastra (Pullet Carpet Shell) by ELISA. Food Agricult Immunol 14:65-71

Fernández-Tajes J, Gaspar M, Martínez-Patiño D et al (2007) Genetic variation of the razor clam Ensis siliqua (Jeffreys, 1875) along the European coast based on random amplified polymorphic DNA markers. Aquac Res 38:1205-1212

Gaffney PM (2006) The role of genetics in shellfish restoration. Aquat Living Resour 19:277-282

Garrido A, Carvalho M (2007) A diáspora dos Ílhavos, Museu Marítimo de Ílhavo. Editora Ílhavo

Harris SA (1999) RAPDs in systematics—a useful methodology? In: Hollingsworth PM, Bateman RM, Gornall RJ (eds) Molecular systematics and plant evolution. Taylor and Francis, London, pp 211-228

Havenhand H (1995) Evolutionary ecology of larval types. In: McEdward L (ed) Ecology of marine invertebrate larvae. CRC Press, Boca Raton, pp 79-122

Heipel DA, Bishop JDD, Brand AR et al (1998) Population genetic differentiation of the great scallop Pecten maximus in western Britain investigated by randomly amplified polymorphic DNA. Mar Ecol Prog Ser 162:163-171

Holmes SP, Dekker R, Williams ID (2004) Population dynamics and genetic differentiation in the bivalve mollusc Abra tenuis: aplanic dispersal. Mar Ecol Prog Ser 268:131-140

Levin LA (2006) Recent progress in understanding larval dispersal: new directions and digressions. Int Comp Biol 46(3):282-297

Li Ma X, Cowles DL, Carter RL (2000) Effect of pollution on genetic diversity in the bay mussel Mytilus galloprovincialis and the acorn barnacle Balanus glandula. Mar Environ Res 50:559-563

Liu B, Dai J (1998) Studies on genetic diversity in oysters Crassostrea. J Fish China 22(3):193-198

Lynch M, Milligan B (1994) Analysis of population genetic structure with RAPD markers. Mol Ecol 3:91-99

Macedo MCC, Macedo MIC, Borges JP (1999) Conchas Marinhas de Portugal. Editorial Verbo, Lisbon

Maia F, Sobral MP, Gaspar M (2006) Ciclo reprodutivo e primeira maturação de Solen marginatus e Venerupis pullastra na Ria de Aveiro. Bases científicas para a gestão destes recursos. Relat. Cient. Téc. IPIMAR, 30

Massapina C, Arrobas I (1991) A cultura de moluscos bivalves na Ria Formosa: estado actual e perspectivas, $1^{\circ}$ Simpósio NOPROT, Faro

Miller MP (1997) Tools for Population Genetic Analyses (TFPGA) 1.3: a Windows Program for the Analysis of Allozyme and Molecular Population Genetic Data. Computer software distributed by author

Moreira MH, Queiroga H, Machado MM et al (1993) Environmental gradients in a southern estuarine system: Ria de Aveiro, 
Portugal, Implications for soft bottom macrofauna colonization. Neth J Aquat Ecol 27:465-482

Nei M (1978) Estimation of average heterozygosity and genetic distance from a small number of individuals. Genetics 89: 583-590

Newton A, Mudge SM (2003) Temperature and salinity regimes in a shallow, mesotidal lagoon, the Ria Formosa, Portugal. Estuar Coast Shelf Sci 57:73-85

Nobre AM, Ferreira JG, Newton A et al (2005) Management of coastal eutrophication: integration of field data, ecosystem- scale simulations and screening models. J Mar Sys 56:375-390

Oliveira FXd'A (1906) Monografia do Concelho de Olhão da Restauração. Algarve em Foco Editora

Ouborg NJ, Piquot Y, van Groenendael JM (1999) Population genetics, molecular markers and the study of dispersal in plants. J Ecol 87:551-568

Palumbi SR (2001) Humans as the world's greatest evolutionary force. Science 293:1786-1790

Pereira J (2008) Perfis de RAPD-PCR em populações de Ruditapes decussatus (Linnaeus, 1758) do sul de Portugal: Avaliação da diversidade genética. Master thesis

Picado A, Dias JM, Fortunato A (2009) Effect of flooding the salt pans in the Ria de Aveiro. J Coast R SI 56:1395-1399

Qian W, Ge S, Hong DY (2001) Genetic variation within and among populations of a wild rice Oryza granulata from China detected by RAPD and ISSR markers. Theor Appl Genet 102:440-449

Reisenbichler RR, Rubin SP (1999) Genetic changes from artificial propagation of Pacific salmon affect the productivity and viability of supplemented populations. ICES J Mar Sci 56:4 59-466

Ropes JW (1979) Biology and distribution of surf clams (Spisula solidissima) and ocean quahogs (Arctica islandica) off the northwestern coast of the United States. Proc Northeast Clam Industries: management for the future. University of Massachusetts and Massachusetts Institute of Technology, Sea Grant Program SP 112:47-66

Schaal BA, Leverich WJ (2001) Plant population biology and systematics. Taxon 50:357-373
Simmons M, Mickett K, Kucuktas H et al (2006) Comparison of domestic and wild channel catfish (Ictalurus punctatus) populations provides no evidence for genetic impact. Aquaculture 252:133-146

Slatkin M (1987) Gene flow and the geographic structure of natural populations. Science 236:187-792

Sofia SH, Silva CRM, Galindo BA et al (2006) Population genetic structure of Astyanax scabripinnis (Teleostei, Characidae) from an urban stream. Hydrobiologia 553:245-254

Star B, Apte S, Gardner JPA (2003) Genetic structuring among populations of the greenshell mussel Perna canaliculus revealed by analysis of randomly amplified polymorphic DNA. Mar Ecol Prog Ser 249:171-182

Toro JE, Ojeda JA, Vergara AM (2004) The genetic structure of Mytilus chilensis (Hupe 1854) populations along the Chilean coast based on RAPDs analysis. Aquac Res 35:1466-1471

Ward RD (2006) The importance of identifying spatial population structure in restocking and stock enhancement programmes. Fish Res 80:9-18

Whitlock MC, McCauley DE (1999) Indirect measures of gene flow and migration: FST not equal to $1 /(4 N \mathrm{~m}+1)$. Heredity 82 : $117-125$

Williams JGK, Kubelik AR, Livak KJ et al (1990) DNA polymorphisms amplified by arbitrary primers are useful as genetic markers. Nucl Acids Res 18:6531-6535

Wright S (1951) The genetic structure of populations. Ann Eugen 15:323-354

Yan J, Liu S, Sun Y et al (2005) RAPD and microsatellite analysis of diploid gynogens from allotetraploid hybrids of red crucian carp (Carassius auratus) $\times$ common carp (Cyprinus carpio). Aquaculture 243:49-60

Yeh FC, Yang RC, Boyle TBJ et al (1997) POPGENE, the UserFriendly Shareware for population genetic analysis. Molecular Biology and Biotechnology Center, University of Alberta, Edmonton

Yu X, Mao X, Wang M et al (2004) Genetic heterogeneity analysis and RAPD marker detection among four forms of Atrina pectinata Linnaeus. J Shellfish Res 3(1):165-172 